\title{
KAPASITAS APARATUR SIPIL NEGARA TERHADAP EFEKTIVITAS PELAYANAN PUBLIK PADA BIDANG PENCATATAN SIPIL DI DINAS KEPENDUDUKAN DAN PENCATATAN SIPIL KOTA SUNGAI PENUH
}

\author{
Hengki Pernanda \\ STIA Nusantara Sakti Sungai Penuh \\ Email : \\ hengkipernanda10@gmail.com
}

\begin{abstract}
Service is a very important task that must be found from the figure of the government apparatus as a servant of the community, namely that the community must carry out its duties that always serve the interests of the community and meet every need of the community in accordance with applicable regulations. Serving and protecting the community is the main function of every government apparatus in carrying out government duties. The services provided by the government apparatus to the community must be in accordance with their authority. The reality that occurs until now there are still complaints from the community such as the unknown requirements, convoluted and also uncertainty in the administration of administration and the attitude of government officials who are less responsive to what is the needs of each community. In carrying out public services there is a tendency for injustice to exist in public services where people classified as poor will find it difficult to obtain services. To find out howcapacity of the state civil apparatus on the effectiveness of public services in the Dinas Kependudukan dan Pencatatan Sipil Kota Sungai Penuh. The approach used in this study is a qualitative study, because it determines and reports the existing situation according to its reality and by measuring it. Typical qualitative research to find out attitudes, opinions, opinions, information, domography, circumstances and procedures. The informants in this study were 8 people. This study uses data collection techniques namely field research, library research, and interviews. From the interviews conducted by the researchers concluded that the services carried out by the Sungai Penuh village office staff were done well and in accordance with public service procedures.
\end{abstract}

Keywords: Service, community

Pelayanan merupakan tugas yang sangat penting yang harus didapati dari sosok aparatur pemerintah sebagai abdi dari masyarakat yaitu bahwa masyarakat harus melaksanakan tugasnya yang seanantisa melayani kepentingan masyarakat dan memenuhi setiap kebutuhan dari masyarakat sesuai dengan peraturan yang berlaku. Melayani dan mengayomi masyarakat merupakan fungsi utama dari setiap aparatur pemerintah dalam penyelenggaraan tugas pemerintah. Pelayanan yang diberikan oleh aparatur pemerintah kepada masyarakat harus sesuai dengan apa yang menjadi kewenangannya. Kenyataan yang terjadi sampai saat ini masih ada keluhan dari masyarakat seperti pada persyaratan yang tidak diketahui, berbelit-belit dan juga ketidakpastian jangka waktu dalam pengurusan administrasi serta sikap aparatur pemerintah yang kurang responsif terhadap apa yang menjadi kebutuhan dari setiap masyarakat. Dalam penyelenggaraan pelayanan publik terdapat kecenderungan adanya ketidakadilan dalam pelayanan publik dimana masyarakat yang tergolong miskin akan sulit mendapatkan pelayanan. Untuk mengetahui Bagaimana Kapasitas Aparatur Sipil Negara dalam pelayanan pada Bidang Pencatatan Sipil di Dinas Kependudukan dan 
Pencatatan Sipil Kota Sungai Penuh.Pendekatan yang digunakan dalam penelitian ini adalah Penelitian Kualitatif, karena hal tersebut menetukan dan melaporkan keadaan yang ada menurut kenyataan nya dan dengan mengukurnya. Penelitian Kualitatif yang tipikal untuk mengetahui sikap, pendapat, opini, informasi, domografi, keadaan dan prosedur. Adapun informan dalam penelitian ini adalah 8 Orang. Penelitian ini menggunakan teknik pengumpulan data yaitu penelitian lapangan, penelitian kepustakaan, dan wawancara. Dari hasil wawancara yang dilakukan peneliti menyimpulkan bahwa pelayanan yang dilakukan oleh pegawai Kantor Dinas Dukcapil Kota Sungai Penuh sudah dilakukan dengan baik dan sesuai dengan prosedur pelayanan publik.

Kata Kunci: Pelayanan, masyarakat

\section{PENDAHULAN}

Menurut Brown Rohdewohld (2005 : 11) Kapasitas merupakan kemampuan manusia, kemampuan institusi dan juga kemampuan sistemnya. Kapasitas tidak hanya berorientasi kepada kemampuan manusia semata-mata.Karena mengingat dalam sebuah sistem organisasi misalnya selain mencakup aspek manusia juga mencakup sistem manajamen, kebijakan, strategi, peraturan dan lain-lain. Istilah kapasitas memiliki beragam pengertian tergantung siapa yang mengartikannya dan dalam konteks apa istilah tersebut akan digunakan.

Dengan menggunakan pengertian yang lebih sederhana, dalam konteks penyelenggaraan pelayanan publik oleh pemerintah daerah maka dapat dikatakan bahwa kapasitas penyelenggaraan pelayanan publik adalah kemampuan pemerintah daerah, baik secara keseluahan, unit-unit perangkat pemerintah daerahnya, maupun individu aparatur pemerintah daerah untuk menghasilkan kinerja dan kualitas layanan publik yang efektif, efisien, dan berkelanjutan.

Menurut Mahmud (2005: 23) pelayanan publik yang diselenggarakan oleh pemerintah mencakup pelayanan masyarakat dan pelayanan administrasi.Kedua hal tersebut beriringan dalam mewujudkan kinerja pelayanan yang baik (good performance) dalam pemerintahan.Tujuan pelayanan publik didukung dengan diberlakukannya Undang-Undang Nomor 23 Tahun 2014 tentang pemerintahan daerah.Penyelenggaraan pemerintahan dalam konteks otonomi daerah diharapkan fasilitas publik dan administrasi publik.

Menurut Lubis (2013 : 104) Tertib administrasi adalah suatu konsep pengembangan pelayanan yang ditujukan kepada penyelenggara administrasi sehingga pelayanan administrasi menjadi lebih efektif dan efisien. Selama ini pelayanan administrasi menjadi terkesan lambat dan tidak efektif karena tidak adanya koordinasi pengawasan dan pendelegasian tugas yang akurat.Tertib administrasi sangat didambakan oleh semua penyelenggara administrasi atau administrator karena pekerjaan yang administrasi membutuhkan ketepatan waktu, kejelasan kerja, keterbukaan dan kesederhanaan agar mereka yang dilayani menjadi puas. Harapan seperti ini tentunya akan mengarah kepada pelayanan publik yang baik, namun demikian pelaksanaan tertib administrasi hingga saat ini menjadi pekerjaan yang rumit bahkan terjadi penundaan pekerjaan yang menyebakan pelayanan publik menjadi tidak efektif.

Sementara itu tertib administrasi menjadi simbol (icon) yang selalu disebut-sebut tetapi tidak diimplementasikan. Pelayanan yang baik akan hanya diwujudkan dengan sistem pelayanan yang mengutamakan kepentingan masyarakat. Hendaknya aparat dalam memberikan pelayanan tidak mendahulukan kepentingan pribadi diatas kepentingan umum.Karena peran aparat disini adalah aparatur Negara sebagai abdi masyarakat.Selain itu 
dalam pelayanan harus sesuai dengan undang-undang atau ketetapan yang berlaku.Sumber daya manusia pun juga sangat berpengaruh dalam pelaksanaan pelayanan.

Pelayanan pencatatan sipil di Dinas Kependudukan dan Pencatatan Sipil Kota Sungai Penuh merupakan salah satu kegiatan pelayanan pemerintah dibidang administrasi kependudukan yang dilakukan oleh Dinas Kependudukan dan Catatan Sipil.Pelayanan tersebut adalah pencatatan dan pengesahan peristiwa penting penduduk untuk menuju kepastian hukum dan tertibnya administrasi kependudukan melalui pencatatan peristiwa kelahiran, perkawinan, perceraian, kematian, pengesahan dan pengakuan anak dan juga kartu tanda penduduk (KTP).Akta kelahiran merupakan hak asasi setiap warga negara guna memperoleh status sebagai seorang anak yang dilahirkan oleh kedua orang tua yang sah atau orang tua kandung. Akta kelahiran memiliki arti yang penting bagi pemerintah yaitu, sebagai salah satu cara menciptakan tertib administrasi kependudukan, pengendalian penduduk, dan data kependudukan yang akurat. Oleh karena itu persepsi masyarakat akan baik atau akan sangat berguna bagi peningkatan kemampuan pegawai dalam memberikan respon yang cepat sehingga hasil yang diterima menjadi kepuasan benar-benar dirasakan masyarakat khususnya didalam organisasi/instansi akan mempermudah dan mempercepat penyelesaian suatu pekerjaan. Bagi masyarakat dengan adanya kualitas pelayanan dan semangat kerja yang baik akan menumbuhkan kepuasan atas pelayanan yang diberikan oleh instansi pemerintah.

Sebagai penyelenggara pelayanan, Dinas Kependudukan dan Pencatatan Sipil Kota Sungai Penuh harus selalu berusaha meningkatkan kompetensi aparaturnya sehingga asas peningkatan pelayanan publik tercapai.Kompetensi adalah kemampuan dan kemauan melakukan tugas (the ability and willingness to perform a task) (Burgoyne, 1988 dalam Sedarmayanti 2007 :125), tujuan dilakukan pelayanan publik pada dasarnya adalah memuaskan masyarakat sebagai suatu kewajiban negara terhadap warganya, olehnya kompetensi aparatur pemerintah sebagai pelayan masyarakat sangat penting, kompetensi yang dimaksud disini bukan hanya latar belakang pendidikan akan tetapi kemampuan pegawai dalam menyelesaikan pekerjaannya serta kemampuan pegawai dalam melayani masyarakat baik terhadap tata cara atau prosedur berperkara serta pengetahuan dan keterampilan dalam menyampaikan informasi.

Tugas utama pemerintah terhadap rakyatnya adalah memberikan pelayanan yang baik dalam rangka memenuhi kebutuhan yang diinginkan oleh masyarakat.Perananan pemerintah memang mengalami perubahan sesuai dengan tuntutan dan dinamika masyarakat yang berkembang. Perubahan apapun yang terjadi terhadap peranan pemerintah pada dasarnya tidak berubah sesuai dengan fungsi pemerintah sebagai pelayan publik atau masyarakat.

Seluruh peristiwa penting yang terjadi dalam keluarga (yang memiliki aspek hukum), perlu didaftarkan dan dibukukan, sehingga baik yang bersangkutan maupun orang lain yang berkepentingan mempunyai bukti yang outentik tentang peristiwa- peristiwa tersebut, dengan demikian maka kedudukan hukum seseorang menjadi tegas dan jelas. Dalam rangka memperoleh atau mendapatkan kepastian kedudukan hukum seseorang, perlu adanya bukti bukti outentik yang sifat bukti itu dapat dipedomani untuk membuktikan tentang kedudukanhukumnya.

Seluruh peristiwa penting yang terjadi dalam keluarga perlu didaftarkan, dibukukan agar yang bersangkutan memiliki bukti yang sah tentang kedudukannya agar dapat dijadikan pedoman dan pembuktian tentang kedudukan hukum seseorang. Salah satu pelayanan yang diberikan pada dinas kependudukan dan catatan sipil adalah pembuatan akta kelahiran. Dimana secara hukum akta kelahiran ini bermanfaat untuk kepentingan anak tersebut.Jika anak tersebut belum memiliki akta kelahiran maka secara hukum keberadaannya dianggap tidak ada oleh Negara.Hal ini mengakibatkan anak tersebut tidak tercatat dalam silsilah kewarganegaraan dan kependudukannya serta tidak terlindungi keberadaannya.Akta 
kelahiran adalah akta catatan sipil dari hasil pencatatan terhadap peristiwa-peristiwa kelahiran seseorang.

Akte kelahiran merupakan suatu bentuk akta yang berwujud berupa selembar kertas yang diterbitkan oleh Dinas Kependudukan dan Catatan Sipil yang berisi informasi mengenai identitas-identitas anak yang dilahirkan yaitu nama, tanggal lahir, nama orang tua, dan tanda tangan pejabat yang berwenang. Dengan demikian akta kelahiran, setiap orang dapat menunjukkan hubungan hukum dengan kedua orang tua.Artinya masyarakat semakin menyadari pentingnya pengurusan akta kelahiran.Sehingga pelayanan terhadap masyarakat untuk pengurusan akta kelahiran ini perlu ditingkatkan agar lebih baik dan lebih professional. Prosedur urusan administrasi apapun telah ditetapkan oleh dinas kependudukan dan catatan sipil Kota Sungai Penuh, pada kenyataannya masih terdapat:

1. Para pelaku pelayanan administrasi seharusnya bekerja secara transparan dan akuntabel dalam memberi pelayanan kepada masyarakat, tetapi kenyataannya sikap dan perilaku para administrator secara psikologis selalu meremehkan pekerjaan pelayanan itu sendiri dan jenuh serta stres kerja yang mengakibatkan pelaksanaan pekerjaan menjadi tidak produktif.

2. Tidak adanya Respon Positif dari aparatur atau petugas pelayanan yang bertugas yang mengakibatkan masyarakat kebingungan dalam penyerahan bahan atau pun persyaratan yang hendak diserahkan.

3. Masih terdapat banyak terjadi kesalah penulisan data yang dilakukan oleh petugas pelayanan, petugas kurang terampil terhadap pelayanan dalam pengurusan KTP, kk, akta, dan lainnya. sehingga memberi dampak terhadap pelayanan menjadi tidak efektif danefesien.

4. Disisi lain informasi yang diperoleh dari petugas pelayanan pengurusan akta kelahiran ini, menyatakan bahwa kesulitan yang sedang dihadapi justru karena masyarakat tidak paham tentang prosedur pengurusan, sehingga pelayanan diberikan terkesan menyulitkan dan berbelitbelit.

\section{METODE PENELITIAN}

\section{Pendekatan Penelitian Yang Digunakan}

Pendekatan penelitian ini sebagaimana mana yang ingin di capai penulis untuk mengimplentasikan pelayanan publik terhadap masyarakat di Kota Sungai Penuh, maka penulis menggunakan pendekatan penelitian kualitatif dengan tipe penelitian deskriptif, penelitian ini dilakukan agar secara runtun untuk memaparkan secara objektif dan rasional mengenai objek penelitian.

\section{Informan Penelitian}

Adapun yang menjadi informan dalam hal ini adalah masyarakat yang berjumlah 8 orang.

\section{Data Yang Akan Diambil}

\section{Data Primer}

Data primer dapat berupa opini subjek secara individual atau kelompok, hasil observasi terhadap suatu benda, kejadian atau kegiatan, dan hasil pengujian.

2. Data Sekunder

Berupa data-data yang telah ada seperti arsip-arsip, dokumen, artikel, serta laporan yang berhubungan dengan objek penelitian.

\section{Teknik Pengumpulan Data Yang Digunakan}


Dalam melakukan penelitian, data yang dikumpulkan akan digunakan untuk memecahkan masalah yang ada sehingga data-data tersebut harus benar-benar dapat dipercaya dan akurat.
a. Wawancara
b. Observasi
c. Dokumentasi
d. Triangulasi

\section{Alata Pengumpulan Data}

Adapun alat yang di gunakan dalam penelitian ini :

1. Daftar pertanyaan / daftar wawancara

2. Laptop

3 Pena, buku tulis/kertas

4. Alat perekam

\section{Unit Analisis}

Dalam penelitian ini fokus penelitian adalah Kepala Dinas Kependudukan dan Pencatatan Sipil Kota Sungai Penuh.

\section{Analisis Data}

Teknik analisis data yang dipakai dalam penelitian ini yaitu analisis model Miles Dan Huberman (1992:16) Yaitu :

1. Reduksi data

Reduksi data diartikan sebagai proses pemilihan, pemusatan perhatian pada penyederhanaan, pengabstrakan, dan transformasi data "kasar" yang muncul dari catatancatatan tertulis dilapangan. Sebagaimana kita ketahui, reduksi data, berlangsung secara terus-menerus selama penelitian yang berorientasi kualitatif berlangsung. Sebenarnya bahkan sebelum data benar - benar terkumpul, antisipasi akan adanya reduksi data sudah tampak waktu penelitiannya memutuskan (acapkali tanpa disadari sepenuhnya) kerangka konseptual wilayah penelitian, permasalahan penelitian dan pendekatan pengumpulan data, terjadilah tahapan reduksi selanjutnya (membuat ringkasan, mengkode, menelusur tema, membuat gugus - gugus, membuat partisipasi, menulis memo).

2. Penyajian data

Alur penting yang kedua dari kegiatan analisis adalah penyajian data. Sebagai sekumpulan informasi tersusun yang memberi kemungkinan adanya penarikan kesimpulan dan pengambilan tindakan Huberman (1992:17)

3. Menarik kesimpulan / verifikasi

Alur kegiatan analsis ketiga adalah menarik kesimpulan dan verifikasi.Dari permulaan pengumpulan data seorang penganalisis kualitatif mulai mencari arti benda- benda mencatat keteraturan, pola-pola, penjelasan, konfigurasi- konfigurasi yang mungkin, alur sebab akibat, dan proposisi. Penelitian yang yang berkopenten akan menangani kesimpulan - kesimpulan itu dengan longgar, tetap terbuka dan skeptis, tetapi kesimpulan sudah disediakan, mula-mula belum jelas, namun mungkin tidak muncul pengumpulan data berakhir, tergantung pada besarnya kumpulan catatan lapangan, pengkodeanya, penyimpanan, dan metode-metode pencarian ulang yang digunakan, kecakapan peneliti, dan tuntutan-tuntutan pemberi dana, tetapi seringkali kesimpulan itu telah dirumuskan sebelumnya sejak awal, sekalipun seorang peneliti menyatakan telah melanjutkannya secara induktif. 


\section{HASIL DAN PEMBAHASAN}

\section{Implementasi Indikator Pelayanan Publik di Dinas Kependudukan dan Pencatatan Sipil Kota Sungai Penuh}

\section{a. Kesederhanaan dalam Proses Pelayanan}

Kesederhanaan dalam proses pelayanan yaitu proses yang mudah, jelas hasilnya sehingga tidak harus berulang-ulang dalam kepengurusannya dan menunggu lama baru bisa memperoleh hasil yang diinginkan oleh masyarakat. Dalam menciptakan prosedur pelayanan publik yang tidak berbelit-belit dan mudah dipahami dan dilaksanakan oleh masyarakat sehingga tidak menimbulkan kebingungan, maka proses kesederhanaan dalam pelayanan administrasi di Dinas Kependudukan dan Pencatatan Sipil Kota Sungai Penuh sangat diperlukan.

Mekanisme pelayanan publik yang sederhana dan tidak berbelit-belit merupakan pelayanan yang sangat membantu dan mudah diterima oleh masyarakat, karena dengan cara ini masyarakat akan terbantu, dengan adanya pelayanan ini masyarakat akan paham langsung dengan penyajiannya yang secara transparansi atau terbuka. Kemudahan dalam proses pelayanan juga sangat dibutuhkan bagi pengguna layanan agar proses pelayanan dapat berjalan lebih cepat.

Secara umum, tanggapan dari respon masyarakat terkait kesederhanaan proses pengurusan adminisrasi di Dinas Kependudukan dan Pencatatan Sipil Kota Sungai Penuh cukup baik.

Berdasarkan hasil wawancara dan observasi penulis dengan beberapa key informan aparatur di Dinas Kependudukan dan Pencatatan Sipil Kota Sungai Penuh dan beberapa informan dari masyarakat, dapat diketahui bahwa dalam proses pelayanan administrasi sudah tergolong sederhana dan cukup mudah dipahami oleh masyarakat. Hal ini menjadi tolok ukur masyarakat menyatakan bahwa di Dinas Kependudukan dan Pencatatan Sipil Kota Sungai Penuh telah memberikan pelayanan yang baik terhadap mereka.

\section{b. Kejelasan Pelayanan Publik}

Jangka waktu penyelesaian layanan adalah rentan waktu yang diberikan kepada pengguna layanan dalam menyelesaikan suatu jenis pelayanan yang diberikan. Kejelasan akan waktu pelayanan merupakan salah satu wujud pelayanan yang prima. Adanya kejelasan tentang berapa lama waktu proses pelayanan akan memberikan kepastian kepada pengguna layanan kapan suatu jenis pelayanan dapat terselesaikan. Tentunya hal ini akan berdampak pada kepercayaan yang ada di masyarakat pada sebuah kantor pelayanan publik tersebut.

Dalam hal ini tampak bahwa pihak Dinas Kependudukan dan Pencatatan Sipil telah berusaha untuk menerapkan prinsip transparansi dalam pengelolaan informasi yang dibutuhkan oleh masyarakat sebagai langkah awal dalam memudahkan proses administratif.

Prosedur pelayanan yang diberikan kepada masyarakat dalam memberikan suatu pelayanan dapat dikatakan cukup baik, hal ini dikarenakan kejelasan atau kepastian serta prosedural, artinya sudah sesuai dengan ketentuan yang berlaku, karena telah ada prosedur dan persyaratan yang jelas dalam pelayanan administrasi kependudukan di Dinas Kependudukan dan Pencatatan Sipil Kota Sungai Penuh. Maka dengan demikian dapat dikatakan bahwa prosedur yang jelas dalam pelayanan yang telah diterapkan sesuai dengan prosedur yang ada yaitu masyarakat harus menyediakan setiap persyaratan yang sesuai dengan ketentuan yang ada.

\section{c. Kepastian waktu Pelayanan Publik}


Waktu penyelesaian pelayanan adalah jangka waktu penyelesaian publik mulai dari dilengkapinya persyaratan teknis dan atau persyaratan administratif sampai dengan selesainya suatu proses pelayanan. Mengenai ketepatan waktu dalam suatu proses administrasi pemerintahan seharusnya ada ketentuan untuk penyelesaian suatu pekerjaan yang prinsipnya cepat, tepat sasaran, dan tidak berbelit-belit serta memberikan kesan yang baik bagi masyarakat.

Kurangnya kedisiplinan para petugas pelayanan juga ikut menentukan tingkat kepuasan masyarakat pengguna jasa layanan. Tinggi atau rendahnya tingkat kedisiplinan di Dinas Kependudukan dan Pencatatan Sipil Kota Sungai Penuh juga akan mempengaruhi dalam proses penyelesaian administrasi.

Kepastian dan kurun waktu penyelesaian pelayanan publik harus diinformasikan secara jelas dan terbuka agar pengguna jasa layanan dapat memastikan berapa lama kurun waktu yang digunakan oleh petugas Dinas Dukcapil Kota Sungai Penuh dalam menyelesaikan proses administrasi yang dikerjakannya.

Berdasarkan hasil wawancara dengan informan, dapat diketahui bahwa kepastian waktu yang diterapkan di Dinas Kependudukan dan Pencatatan Sipil Kota Sungai Penuh tergolong cepat dan sudah berjalan sesuai aturan yang diterapkan. Hanya saja yang sering menjadi kendala dalam hal ini adalah jika terjadinya kesalahan teknis yang dapat menyebabkan terbengkalainya proses pelayanan. Tentunya ini merupakan sebuah tantangan yang tersendiri bagi aparatur camat dalam mengatasi hal tersebut agar pelayanan yang diterapkan tepat sasaran.

\section{d. Ketelitian Petugas (Akurasi) Dalam Pelayanan Publik}

Penyelenggaraan pemerintahan yang baik pada dasarnya menuntut keterlibatan seluruh komponen pemangku kepentingan untuk memberikan pelayanan yang sesuai dengan kebutuhan masyarakat. Tingkatan keakurasian para pegawai yang berada di Dinas Kependudukan dan Pencatatan Sipil dalam setiap proses pengurusan administrasi juga mendorong terciptanya pelayanan publik yang terpercaya dan sesuai dengan kebutuhan masyarakat.

Berdasarkan hasil wawancara dengan berbagai key informan dan informan dari masyarakat, maka dapat disimpulkan tingkat keakurasian dalam proses pelayanan administrasi tergolong baik dan sesuai dengan kebutuhan masyarakat. Salah satu ukuran yang paling penting dari kinerja pelayanan publik adalah tingkat ketelitian petugas pelayanan dalam menyelesaikan suatu pekerjaan. Yang dimaksud dengan ketelitian petugas yaitu bekerja secara profesional sesuai dengan tugas masing-masing.Dengan adanya ketelitian petugas, memungkinkan bagi setiap petugas untuk mencurahkan pemikiran, perhatian dan kemampuannya dalam menjalankan tugas-tugas pekerjaan yang menjadi tanggung jawabnya.Dari aspek ini setelah dianalisa berdasarkan hasil wawancara yang dilakukan, bahwa tingkat ketelitian petugas dalam memberikan pelayanan sudah cukup baik, petugas sudah memberikan pelayanan yang akurat sehingga menghasilkan kinerja pelayanan yang memuaskan. Hal tersebut dibuktikan melalui wawancara dengan key informan, Bapak Zamroni, SH.,MH.

\section{e. Tanggung jawab Dalam Pelayanan Publik}

Tanggung jawab yang dimaksud disini yaitu tanggung jawab petugas administratif.Tanggung jawab berarti kesanggupan seorang pegawai untuk menyelesaikan pekerjaan yang diserahkan kepadanya dengan sebaik mungkin dan tepat padawaktunya serta berani memikul resiko atau keputusan yang diambilnya atau tindakan yang dilakukannya.Menurut Surjadi (2009) mengatakan tanggung jawab merupakan kejelasan wewenang dan tanggung jawab petugas dalam menyelenggarakan dan penyelesaian pelayanan kepada masyarakat. 
Administrator negara harus bertindak berdasarkan tanggung jawab moral yang mereka sadari terhadap publiknya. Misalnya, administrator negara (birokrat) perlu bersikap adil, tidak membedakan client, peka terhadap ketimpangan yang terjadi dalam masyarakat atau memegang teguh kode etik sebagai pelayan publik.Yang termasuk dalam unsur tanggung jawab terdiri atas sub-sub unsur sebagai berikut :

1. Menyelasaikan tugas dengan baik dan tepat waktunya.

2. Tidak melemparkan kesalahan kepada orang lain.

3. Menyimpan dan memelihara barang milik barang milik negara yang dipercayakan kepadanya.

4. Dalam segala keadaan tetap berada ditempat tugas.

5. Mengutamakan kepentingan dinas dari pada kepentingan diri sendiri, orang lain atau golongan.

6. Berani dan ikhlas memikul resiko.

Kecermatan atau ketelitian petugas dalam melayani pengguna layanan sangat penting bagi proses pelayanan. Jika petugas tidak cermat dalam melayani masyarakat, maka akan terjadi kesalahan dan menimbulkan masalah baru. Maka dari itu petugas harus cermat dalam mengerjakan tanggung jawab tugas khususnya yang berkaitan dengan pelayanan agar tercipta pelayanan yang baik dan masyarakat akan menilai dengan baik.

Berdasarkan hasil wawancara dengan key informan dan informan dari masyarakat, dapat diketahui bahwa petugas pelayanan di Dinas Kependudukan dan Pencatatan Sipil Kota Sungai Penuh telah menjalankan tanggung jawabnya sesuai dengan tupoksi. Hal ini menjadi suatu keharusan bagi mereka agar setiap pekerjaan yang dilakukan harus didasari oleh prinsip sebagai bentuk pertanggung jawaban untuk menghindari kesalahan dalam proses pelayanan.

\section{SIMPULAN}

Secara konseptual, kapasitas dalam pelayanan publik adalah segala kegiatan pelayanan yang dilaksanakan oleh penyelenggara pelayanan publik sebagai upaya pemenuhan kebutuhan penerima pelayanan maupun pelaksanaan ketentuan peraturan perundang-undangan, yang bersifat terbuka, mudah, dan dapat diakses oleh semua pihak yang membutuhkan serta disediakan secara memadai dan mudah dimengerti oleh semua penerima kebutuhan pelayanan.

Mengingat jenis pelayanan sangat banyak dengan sifat dan karakteristik yang beragam, maka dalam memenuhi pelayanan diperlukan pedoman yang digunakan sebagai acuan bagi masyarakat.Untuk memudah peneliti dan menghemat waktu dalam penelitian.Berdasarkan uraian pada BAB III yang menyajikan hasil penelitian dan pembahasan, maka dapat disimpulkan sebagai berikut :

1. Indikator kesederhanaan dalam proses pelayanan yang cukup sederhana dan mudah dipahami oleh masyarakat Kesederhanaan dalam proses pelayanan yaitu proses yang mudah, jelas hasilnya sehingga tidak harus berulang-ulang dalam kepengurusannya dan menunggu lama baru bisa memperoleh hasil yang diinginkan oleh masyarakat. Dalam menciptakan prosedur pelayanan publik yang tidak berbelit-belit dan mudah dipahami dan dilaksanakan oleh masyarakat sehingga tidak menimbulkan kebingungan, maka proses kesederhanaan dalam pelayanan administrasi di Dinas Kependudukan dan Pencatatan Sipil Kota Sungai Penuh sangat diperlukan.

2. Adanya kejelasan prosedural dan informasi yang sangat membantu masyarakat, semua proses / alur bahan yang ingin dibuat harus ada kejelasan sehingga semua mudah dipahami oleh masyarakat yang berkepentingan. 
3. Kepastian waktu yang diterapkan di Dinas Kependudukan dan Pencatatan Sipil Kota Sungai Penuh tergolong cepat dan sudah berjalan sesuai prosedur yang berlaku,

\section{UCAPAN TERIMAKASIH}

Diucapkan terima kasih kepada semua pihak yang telah berkontribusi dalam penulisan jurnal ini, sehingga jurnal ini dapat diselesaikan dengan baik. Dan juga terima kasih kepada penglola jurnal Qawwam, sehingga bisa dipublikasan di OJS Qawwam.

\section{DAFTAR PUSTAKA}

\section{A. Buku-buku}

Afrial J,R. 2009. Kualitas Pelayanan Publik Kecamatan setelah perubahan Kedudukan dan fungsi Camat sebagai Daerah. Jurnal Ilmu Administrasi Dan Organisasi, 16(2), 8795.

Anwar, 2010.Reformasi Demokrasi melalui Peningkatan Kualitas Pelayanan Publik Dan Penanganan Pengaduan Berbasis Masyarakat.

Ar, Mustopadidjaja. 2002, Manajemen Proses Kebijakan Publik, Formulasi, Implementasi dan Evaluasi Kinerja, Jakarta:LAN.

Pebi Julianto. 2018. Pengaruh Pengetahuan dan Keterampilan Terhadap Prestasi Kerja Pegawai Pada Mtsn Model Sungai Penuh. E Jurnal Administrasi Nusantara. Sungai Penuh.

Fitzssimon, 2002, Manajemen Pelayanan Publik, Terjemahan, Bumi Aksara Indonesia, Jakarta.

Hamdi, 2001, Transparansi dalam Konteks Pelayanan Publik, Jakarta: LAN

Juliantara, 2005.Asas Pelayanan Publik,Jakarta: Raja Grafindo.2012.

Pebi Julianto. 2018. Pengaruh Sistem Kearsipan Terhadap Efisiensi Kerja Pada koantor Camat Air Hangat Kabupaten Kerinci. E Jurnal Administrasi Nusantara. Sungai Penuh.

Mahmud. 2005, Public Service.Terjemahan, Bumi Aksara Indonesia, Jakarta.

Milles, Matthew B Dan A. Michael Huberman. 1992. Analisis Data Kualitatif:Universitas Indonesia.

Moenir, 1995, Manajemen Pelayanan Umum Indonesia, Bumi Aksara Indonesia, Jakarta.

Mardiasmo, 2002:19. Transparansi dalam Pelayanan Publik.

Mestika Zed, 2008.,Penelitian Kualitatif,Bumi Aksara Indonesia, Jakarta. 
Narbuko, Cholid, Dan Abu Achmadi 2004. Metode Penelitian.Jakarta:Bumi Aksara.

Notoatmojo, Ssoekidjo, 2012. Promosi Pelayanan Publik.

Nurmita, 2015, Administrasi Negara STIA, Analisis Transparansi Pelayanan dalam Publik, Rawang.

Pebi Julianto. 2019. Pengaruh Disiplin Kerja Terhadap Prestasi Kerja Pegawai pada Puskesmas di kecamatan Depati VII Kabupaten Kerinci. E Jurnal Administrasi Nusantara. Sungai Penuh.

Paul H. Dauglas, Wahyudi Kumorotomo 1992. Ketentuan Transparansi dalam Pelayanan Publik.

Ratmito dan Winarsih, A.S. 2006. Manajemen Pelayanan. Yogyakarta:Pustaka Pelajar.

Sinambela, Lijan Poltak. 2005. Reformasi Pelayanan Publik, Teori, Kebijakan, dan Implementasi. Jakarta : PT. Bumi Aksara.

Siagian, Sondang P.2008. Manajemen SUmber Daya Manusia. Jakarta : PT. Bumi Aksara Sugiyono, 2012. Metode Penelitian Kualitatif dan R dan D. Bandung : Alfabeta.

Sedarmayanti, 1999, Manajemen Pelayanan Publik, Raja Wali Pers, Jakarta.

Pebi Julianto. 2014. Evaluasi Pelaksanaan Program Satu milyar Satu kecamatan (Samisake) di kecamatan Depati Tujuh Kabupaten Kerinci Provinsi jambi tahun 2014. OSF Preprints. Jakarta.

Wasistiono, Sadu, 2002. Tentang Pentingnya Pelayanan Publik dan Pelayanan Umum.

Widodo, Joko. 2001. Good Governance : Telaah dan Dimensi Akuntabilitas dan Kontrol Birokrasi pada Era Desentralisasi dan Otonomi Daerah, Insan Cendekia : Surabaya.

Zeithami, valarie A. , 1990. Delivering Quality Services, Bumi Aksara, Jakarta.

Zeithaml, Valare A., 1990, Delivering Quality Services, edisi revisi, Bumi Aksara, Jakarta.

\section{B. Undang-Undang / Peraturan-peraturan}

Undang-undang Nomor 25, Tahun 2009, Pelayanan Publik.

Undang-undang Nomor 9, Tahun 2015, Pemerintah Daerah.

KepMenpan NO: 63/KEP/M.PAN/7/2003, Tahun 2003 Tentang Pedoman Umum Penyelenggaraan Pelayanan publik, Jakarta. 